\title{
UČENJE KROZ PRIZMU SOCIJALNOG KONSTRUKTIVIZMA
}

\author{
Jasmina VRkić Dimić \\ Sveučilište u Zadru, Odjel za pedagogiju \\ University of Zadar, Department of pedagogy \\ UDK: 37.02 \\ Prethodno priopćenje / Preliminary communication \\ Primljeno / Received: 28. XI. 2011.
}

\begin{abstract}
U današnjim shvaćanjima čovjekovog razvoja i učenja sve više se ističe značaj kontekstualnih, posebice socijalnih utjecaja, kao i njihovog dinamičnog međudjelovanja na pojedinca i, obrnuto, pojedinca na njih. Dinamična su-konstrukcija navedenih odnosa izgrađuje pojedinca, pri čemu je on aktivan akter dinamike promjena do kojih dolazi kod njega, ali i u njegovoj okolini. Znanja, sposobnosti, kompetencije konstruiraju se temeljem čovjekovog postojećeg iskustva te konteksta u kojem se učenje događa. Temeljne promjene u učenju i poučavanju su prijelaz na otvoreni sustav znanja i usmjerenje na sâme procese učenja. Učenje i poučavanje se otvaraju te se promatraju u daleko širem materijalnom, socijalnom, kulturnom kontekstu od onog uskog nastavnog. Sve to zahtijeva redefiniranje kurikuluma, kreiranje poticajnog okruženja učenja i poučavanja, ali i promijenjeni opći pristup u obrazovanju nastavnika.

U radu se kratko iznose aktualne konstruktivističke interpretacije učenja i konteksta u kojem se ono odvija. Poseban naglasak stavlja se na socijalni konstruktivizam, zajednice prakse/učenja i informalne oblike učenja. Daje se pregled izmijenjene perspektive o učenju kroz niz od sedam principa te, u konačnici, refleksije teorije socijalnog konstruktivizma na praksu školskog učenja i poučavanja.
\end{abstract}

KLJUČNE RIJEČI: informalno učenje, konstruktivizam, kontekst, poučavanje, principi učenja, socijalni konstruktivizam, učenje, zajednice prakselučenja

\section{UvOD}

Jedna od važnih karakteristika dobrih znanstvenih teorija je suglasnost. To znači da je teorija suglasna i usklađena s općim dominirajućim pogledom na svijet. Opći pogled na svijet ne predstavlja povijesnu konstantu, već je podložan stalnim izmjenama, preinakama, a ponekad i naglim obratima. Tako se, npr. na čovjekov razvoj i učenje u doba biheviorizma gledalo kao na reaktivan proces, a na čovjeka kao na determinirano biće. Iako se priznavao utjecaj i nasljeđa i okoline na čovjekov razvoj i učenje, smatralo se da je čovjekova pozicija pritom pasivna. Nakon toga uslijedio je humanistički period u kojem se čovjeka promatralo kao kreativno, proaktivno biće (Lacković-Grgin, 2006). Terhart (2003) navodi kako je došlo do kognitivnog obrata u okviru kojeg se na učenje počelo gledati kao na obradu informacija. Iako je učenik time postao aktivan akter učenja s povećanim stupnjem slobode u odlučivanju i djelovanju, ipak je pristup obrade informacija i dalje predstavljao svojevrstan prošireni, liberalni biheviorizam. 
Takva su se shvaćanja odrazila na praksu učenja i poučavanja kroz zahtjeve za učenikovom središnjom pozicijom u odgojno-obrazovnom procesu. Na učenika se počelo gledati kao na aktivan subjekt koji upravo svojom aktivnošću i kreativnošću neposredno sudjeluje u ostvarivanju ciljeva učenja i poučavanja. Metode učenja i poučavanja, sukladno tome, okretale su se prema aktivnim oblicima učenja. Dakle vidi se kako je došlo do pomaka u općem pogledu na svijet; krenulo se od determinističkog, hijerarhijski organiziranog pogleda, uz naglašeno centralizirano donošenje odluka, racionalnost i kontrolu, te je stvoren novi pogled na svijet koji nije determiniran, već vjerojatan i decentraliziran (Terhart, 2003).

U posljednje se vrijeme čovjekov razvoj i učenje promatraju u kontekstu kompleksnih sustava odnosa između čovjeka i socijalnih, materijalnih te kulturnih utjecaja, iz njegovog užeg i šireg okolinskog konteksta, koji u svojem aktivnom međudjelovanju oblikuju pojedinca i okolinu (Lacković-Grgin, 2006). Svijet je, prema novom tumačenju, sazdan od brojnih jedinica složenih u mreže, koje prate uvjetno predvidivi smjerovi događaja (Terhart, 2003). S takvim shvaćanjima sve se više uviđa značaj kontekstualnih, posebice socijalnih utjecaja te njihovog dinamičnog međudjelovanja na pojedinca i obrnuto, pojedinca na njih. Smatra se da upravo ta dinamična su-konstrukcija odnosa izgrađuje pojedinca, a pojedinac je pritom bitan i aktivan akter dinamike promjena do kojih i kod njega i u okolini dolazi. Ovakva razmišljanja, osim što učenika stavljaju u središnju i aktivnu poziciju u odgojno-obrazovnom procesu, sâmo učenje i poučavanje otvaraju te se oni promatraju u daleko širem materijalnom, socijalnom, kulturnom kontekstu od onog uskog nastavnog.

\section{KONSTRUKTIVISTIČKE INTERPRETACIJE UČENJA}

Aktualne interpretacije učenja i poučavanja učenje razumijevaju kao proces konstruiranja znanja. Ono predstavlja aktivnost koja se neovisno izvodi, ali je snažno položena u konkretne situacije (Becker i Riel, 2000; Witfelt, 2000; Terhart, 2003; Gorodetsky i sur, 2003; Saab i sur., 2005; Babić, 2007). Znanje, sposobnosti, sadržaji i sl. se ne stječu, ne "prenose", već se konstruiraju temeljem postojeće strukture, tj. čovjekovog proživljenog iskustva. Iskustvo predstavlja polazišnu točku za interpretiranje dijelova informacija, koje dovodi do učenja - konstruiranja znanja. Pritom je učenje u velikoj mjeri određeno kontekstom u kojem se događa. Učenik razumije vlastite procese učenja: on potiče i nadzire svoj proces učenja, svjestan je uvjeta pod kojima najbolje uči i u skladu s njima organizira svoje učenje (Terhart, 2003; Babić, 2007). To refleksivno razumijevanje vlastitih procesa učenja pospješuje sâmo učenje, ali određuje i njegovu strukturu. Evolucija razumijevanja učenja kretala se od ideja učenja kao procesa kontroliranog vanjskim čimbenicima do razumijevanja učenja koje je pod utjecajem unutarnje individualne strukturiranosti subjekta koji uči, ali i konteksta u kojem se učenje događa. Opći teorijski okvir ovako shvaćenog učenja čini teorija konstruktivizma.

Koncept konstruktivizma možemo smatrati inačicom spoznajne teorije. Prvotne teorijske naznake konstruktivizma i njegov opis dao je Piaget, a 1980. godine Papert je razvio konstruktivizam u praktičnoj varijanti potpomognut računalom, ili, kako ga neki autori nazivaju, - konstrukcionizam (Kretchmar, 2008). Od svojih začetaka konstruktivizam je doživio značajan razvoj. Jedan od često susretanih termina koji 
proizlaze iz konstruktivističkog viđenja učenja i poučavanja je kontekstualizam. Prema njemu su sadržaji, metode i pogledi na svijet uronjeni u situacije učenja te iz njih proizlaze (Wenger, 1991, 1996; Gorodetsky i sur, 2003). Iz navedenog je razvidno da se radi o različitom razumijevanju koncepata koji su povezani s procesima učenja i konstruiranja znanja, u odnosu na one tradicionalne.

Konstruktivizam se vrlo različito tumači, ali ono što je zajedničko različitim tumačenjima, a odnosi se na učenje i poučavanje je: konstruktivna narav spoznaje i znanja, njihova relativnost i procesualnost, usmjerenost na subjekt, utemeljenost na iskustvu i općenito relativizam. Temeljne promjene u učenju i poučavanju su prijelaz na otvoreni sustav znanja i usmjerenje na sâme procese učenja, raznovrsne i brojne razine iskustva učenja te na prepoznavanje specifičnih postignuća učenja (Babić, 2007). Refleksije konstruktivizma u odgojno-obrazovnoj praksi zahtijevaju redefiniranje kurikuluma, kreiranje poticajnog okruženja učenja i poučavanja te promijenjeni pristup u obrazovanju nastavnika u formalnim i neformalnim obrazovnim kontekstima (Witfelt, 2000; Gorodetsky i sur, 2003; Terhart, 2003; Babić, 2007). U protivnom, usprkos danas dominantnom relativističkom pogledu na svijet i aktualnim konstruktivističkim teorijskim interpretacijama učenja i poučavanja, navedeni će se procesi u praksi odgoja i obrazovanja još dugo zadržati u tradicionalnim okvirima. Točnije rečeno, iako se autentično učenje ostvaruje kroz kontekstualne procese konstruiranja znanja, školska praksa učenja i poučavanja još uvijek najčešće nije s time usklađena. To rezultira krizom obrazovanja, a može se jednostavno i zorno potkrijepiti empirijskim podatcima, primjerice rezultatima posljednje Pisa 2009 studije. Oni ilustriraju alarmantan obrazovni problem u Hrvatskoj - učenici su "ugušeni" potrebom zapamćivanja (najčešće kratkoročnog) ogromne količine činjeničnih informacija i često upitno nužnih generalizacija, dok istodobno njihova primjenjivost u konkretnim problemskim situacijama i njihovo dublje razumijevanje vrlo često izostaju. Temeljni uzrok takve situacije je raširena praksa dekontekstualiziranog učenja i poučavanja.

\section{I.I. KONTEKST U SVJETLU KONSTRUKTIVIZMA}

Što je to kontekst i na koji se način u okviru konstruktivizma interpretira? Kontekst je neodvojiv od onoga što se uči. On je imanentni dio situacije učenja, utječe na aktivnosti i procese učenja. Procesi učenja pritom ne otkrivaju značenje svojstveno realnosti, već daju specifično značenje, interpretaciju realnosti. Predodžba značenja smještena je, dakle, u određeni kontekst. Subjektivne koncepcije sudionika učenja, njihovi svjetonazori, vrijednosti, stavovi, sve to bôja konstruirano znanje (Gorodetsky i sur., 2003).

Van Oers je 1998. godine ponudio tri interpretacije konteksta, koje su relevantne za konstruiranje značenja tijekom procesa učenja (Gorodetsky i sur., 2003):

1) Kontekst kao mentalna okolina. Riječ je o kognitivnoj strukturi učenika, o njegovim predznanjima koja su uključena u situaciju učenja i koja omogućuju konstruiranje značenja (smisla). Međutim, mentalna okolina uključuje i dodatne individualne osobine kao što su predispozicije, motivaciju i osobnost. One su dio kognitivnoafektivnog konteksta učenika te utječu na proces konstruiranja jednako kao i prethodno konstruirana znanja, tj. predznanja. 
2) Kontekst kao smislena situacija učenja. Značenje ili smisao proizlazi iz eksternih socijalnih situacija. Kako smislenost određene situacije može biti različita za različite ljude, ona dovodi do različitog razumijevanja i različitih postupaka. Upravo različito značenje učenja za učenike rezultira autentičnim učenjem i procjenjivanjem.

3) Kontekst kao aktivnost. Kontekst je uvijek položen u povijesno-kulturne aktivnosti. Takva šira društvena aktivnost integrira ljudsko djelovanje u koherentnu cjelinu i osigurava temelje za učenikove smislene interpretacije te za njegove postupke. Učenik interpretira prikladne aktivnosti temeljem njegovih prethodnih iskustava i trenutnih ciljeva, što zauzvrat postaje kontekst djelovanja koji osigurava koherentnost između konkretnih postupaka, korištenih alata, simbola i vrijednosti. Sve to oblikuje učenje u specifičnim situacijama.

Sva tri navedena značenja konteksta zajedno daju ukupnost mogućih interpretacija konteksta učenja i sve ih prilikom učenja i poučavanja treba uzeti u obzir. Pojedinac se, kao član zajednice učenja/prakse, angažira u aktivnostima koje potječu od njegovih znanja, interesa, potreba. Konstruirano znanje pritom odgovara njegovim potrebama i preferencijama unutar šireg povijesno-kulturnog konteksta. Znanje se pojavljuje kroz djelovanje, akciju pojedinca, te nosi subjektivan okus onoga koji uči. Takvo je znanje kontekstualno, nije hijerarhijsko, niti linearno te je prije fragmentirano nego koherentno.

Kontekst učenja i poučavanja sjedinjuje individualne specifičnosti pojedinca i njegovu aktivnost unutar šireg socijalnog i povijesno-kulturnog okruženja. Dok umjereni konstruktivizam podjednaku pozornost obraća svim navedenim segmentima konteksta, različitim prenaglašavanjem pojedinih tumačenja konteksta izdvajaju se različita usmjerenja unutar konstruktivizma. Kod radikalnog konstruktivizma, naglasak je na individualno specifičnoj mentalnoj okolini pojedinca te na potpuno subjektivnim interpretacijama realnosti. S druge strane, socijalni konstruktivizam u prvi plan ističe socijalne utjecaje unutar šireg, a posebice specifičnog uskog socijalnog konteksta (tzv. zajednica prakse i/ili učenja), unutar kojih se učenje i poučavanje (tj. aktivno sukonstruiranje značenja i znanja) odvijaju, ali koji predstavljaju i osnovnu pretpostavku za realizaciju procesa učenja i poučavanja.

Često se na konstruktivizam gleda kao na "obećavajuću" teoriju učenja i poučavanja (Terhart, 2003; Babić, 2007). Brojni su pokušaji da se premosti rascjep koji postoji između školskog sustava i općih socijalno-kulturnih tendencija unutar kojih su škole smještene. Takve pokušaje neki nazivaju "novim pedagogijama", "novim didaktikama", ali, prije svega, radi se o nastojanjima da se učenje i poučavanje promatraju kao procesi usko povezani uz širi kontekst, tj. okruženje u kojem se događaju (Terhart, 2003; Babić, 2007). U školama treba prepoznati i priznati odlučujuću ulogu koju igra kontekst u konstruiranju značenja. Trebao bi biti dio zadaća u koje su učenici uključeni, dio rasprava o temama koje se uče (Gorodetsky i sur., 2003). Priznavanje ključne važnosti okruženja učenja, tj. konteksta, utječe na promijenjeni opći pristup prema prirodi učenja i poučavanja. 


\section{SOCIJALNI KONSTRUKTIVIZAM}

Ljudi su društvena bića. Iako živimo u širim društvima, za procese učenja i razvoja osnovno je naše sudjelovanje u manjim društvenim zajednicama i njihovim kulturnim praksama. One osiguravaju temelj pomoću kojeg naši postupci i znanje dobivaju konkretno značenje i smisao. Bez obzira na vrijednost pojedine informacije, ona je sama po sebi besmislena sve dok se ne osmisli u kontekstu socijalnih praksi. Čak je i svakom pojedincu svojstven identitet uvjetovan pripadanjem određenim širim i užim socijalnim zajednicama. To znači da se sudjelovanjem u socijalnim zajednicama konstruiraju znanja i značenja. Učenje je, dakle, socijalni fenomen (Wenger, 1991).

Učenje i razvoj događaju se u procesima dinamičnog i promjenjivog sudjelovanja u kulturnom i socijalnom kontekstu kroz aktivan doprinos pojedinca, sudionika socijalne interakcije. Učenje se ostvaruje iz početnih pozicija imanentnih određenoj tradiciji i kulturi uz korištenje različitih tehnologija i materijala te je obojeno postojećim vrijednosnim sustavom pojedinca (Wenger, 1991, 1996; Babić, 2007). I pojedinci i osobe s kojima su u socijalnoj komunikaciji, kao i aktivnosti u kojima sudjeluju, podložni su kontinuiranoj transformaciji i razvoju, te su određeni međusobnim uzajamnim djelovanjem. Aktivan proces učenja uključuje i učenje učenja koje podrazumijeva i različite načine učenja s drugima i učenje korištenja različitih artefakata kulture, primjerice suvremene tehnologije (Babić, 2007).

Ovakve predodžbe o socijalno utemeljenim procesima učenja sve više dobivaju na relevantnosti kako se naše društvo kreće prema uslužnom modelu proizvodnje (SuárezOrozco, Sattin, 2007). U njemu upravo socijalni procesi, kao što su komuniciranje, konstruiranje razumijevanja i stvaranje značenja, sve više postaju osnovom rada. Dolaženje do rješenja praktičnih problema često se događa kroz informalne razgovore. Međutim rijetko se u okviru formalnog obrazovanja takva vrsta razgovora prepoznaje, poštuje i potiče kao vrijedna informalna aktivnost učenja. Postojeće društvene institucije (npr. škole, poduzeća i sl.) su rasadnici učenja. One stoga trebaju biti vođene s odgovornošću za razvijanjem, podržavanjem i njegovanjem zajednica prakse od kojih su sazdane i u kojima se učenje ostvaruje (Wenger, 1991, 1996, 1998, 2004; Eckert, Wenger, 1994; Snyder, Wenger, Briggs, 2004). Pojam zajednica prakse ruši ustaljenu šablonu individualnog učenja, nudeći nove putove bavljenja učenjem.

Naše su obrazovne ustanove uglavnom zasnovane na pretpostavci da je učenje individualni proces s točno definiranim početkom i krajem i da ga je najbolje odvojiti od ostalih aktivnosti (Wenger, 1991, 1996). Zašto se o učenju često razmišlja kao o individualnoj djelatnosti pojedinca, individualnom stjecanju znanja? Proces učenja povezujemo s nastavnicima predavačima ("prenositeljima znanja"), školskim učionicama ili s usamljenim čovjekovim naporom uloženim u mukotrpno učenje. O knjigama razmišljamo kao o riznicama informacija i neupitnih znanja koja su pretočena u riječi i koje su tu kako bi ih usvojili uz pomoć individualnog mišljenja. Pojedinačne se sposobnosti mjere pomoću standardiziranih testova koji obuhvaćaju samo pojedina "standardizirana" područja čovjekove inteligencije, dok se na ostala područja inteligencije previše ne obaziremo i ne iskorištavamo njihove potencijale. Wenger (1991) ovakva, u našoj kulturi duboko ukorijenjena razmišljanja, naziva mitovima o učenju; zabludama o stjecanju znanja i zabludama o individualnom učeniku. Kada je riječ o učenju, učenik kao da egzistira u svojevrsnom socijalnom i kulturnom vakuumu. Tako su organizirane učionice gdje je 
učenicima ("oslobođenima" svih aktivnosti koje su rezultat njihova sudjelovanja u svijetu) omogućeno pozorno praćenje nastavnikova predavanja i posvećivanje uvježbavanju i ponavljanju. Školsko obrazovanje često se provodi na načine koji polaznicima ne osiguravaju angažman u stvarnoj praksi, u socijalnom životu raznovrsnih zajednica. Učenička se znanja i sposobnosti procjenjuju testovima u kojima se naučeni sadržaji i vještine trebaju prikazati izvan konteksta. Dakle osobni napredak u učenju procjenjuje se pomoću instrumenata koji ne omogućuju uvid u njegovu stvarnu bit (Wenger, 1991, 1996). Sve je to dovelo do iluzije da učenje nije dio svakodnevnog života, već da zahtijeva posebno okruženje, da je učenje isključivo rezultat individualnog napora pojedinca, da je ono teško i da su ljudi često loši u njemu (Wenger, 1991). Iz tih razloga, većinu nastavnih sadržaja učenici vide kao irelevantne, nepovezane sa stvarnim životom izvan škole, a time i dosadne (Wenger, 1996).

Mogući novi pogled na učenje nudi skupina znanstvenika zaposlenih na Institute for Research on Learning - IRL u Kaliforniji, koju predvodi E. Wenger. Oni ističu socijalno orijentirane poglede na učenje utemeljene na postojanju zajednica prakse (communities of practice) u kojima se učenje odvija. Riječ je o inačici konstruktivizma, tzv. socijalnom konstruktivizmu (kojeg pojedini autori nazivaju kontekstualizmom; npr. "kontekstualna pedagogija" - Gorodetsky i sur., 2003). Na Institutu se kroz socijalni pristup učenju analiziraju putevi i načini na koje se ljudsko znanje stvara, odražava i transformira unutar zajednica prakse. Na učenje se gleda kao na odvijajući oblik članstva, tj. sudjelovanja u zajednicama prakse. Učenje se prirodno pojavljuje kroz čovjekov angažman u djelatnostima i aktivnostima takvih zajednica (Wenger, 1991, 1996, 1998, 2004; Eckert, Wenger, 1994; Snyder, Wenger, Briggs, 2004).

\section{I. ZAJEDNICE PRAKSE I INFORMALNO UČENJE}

Svi mi, na poslu, u školi, u svojim privatnim aktivnostima pripadamo brojnim i raznovrsnim zajednicama prakse. One se nalaze svugdje oko nas, uključujući najrazličitije situacije učenja (Wenger, 1991, 1996, 1998, 2004; Eckert, Wenger, 1994; Witfelt, 2000; Snyder, Wenger, Briggs, 2004). Mogu biti formalne, neformalne, informalne. Međutim, češć se ne podudaraju s formalnim skupinama koje postoje u organizacijama (npr. u školama - razredni odjeli, u poduzećima - radne jedinice i timovi, i sl.). Iako škola učenike dijeli u razredne skupine, njihove su stvarne zajednice prakse - učeničke vlastite vršnjačke i prijateljske informalne socijalne skupine. Nažalost, često smo naviknuti na razmišljanje u formalnim terminima, pa previđamo prožetost naših života informalnim utjecajima koji mogu biti izuzetno snažni. Zajednice prakse predstavljaju sredine u kojima se odvijaju određeni poslovi. One imaju svoju vlastitu dinamiku, svoja pravila, "jezik" i strukturu moći. Često se gotovo spontano organiziraju oko onoga što je važno njihovim članovima, a ne prema institucionalnim odlukama, pa se pojavljuju, mijenjaju i iščezavaju, mogli bismo reći - žive vlastitim životom. Kada se npr. na radnom mjestu instalira novi računalni sustav često se stvara informalna zajednica. Kroz pripadnost toj skupini i uključenost u aktivnosti i procese koji se unutar nje odvijaju, njeni članovi uče koristiti novi računalni sustav (Wenger, 1991). Riječ je o socijalnom konstruktivizmu koji naglasak stavlja na socijalne skupine - zajednice prakse, unutar kojih se odvija učenje - zajedničko sukonstruiranje znanja (Witfelt, 2000). 
Nove participirajuće kulture predstavljaju idealna okruženja učenja. Riječ je o informalnim kulturama učenja kojima različiti autori daju razne nazive, kao što su "prostori afiniteta" (Gee, 2004) ili "zajednice prakse" (Wenger, 1991, 1996, 1998, 2004; Eckert, Wenger, 1994; Snyder, Wenger, Briggs, 2004). Sudjelovanjem u njima premošćuju se razlike u dobi, staležima, spolu, rasi i obrazovnoj razini. U njima ljudi participiraju na različite načine, ovisno o njihovim interesima i vještinama. One omogućuju da se svaki sudionik osjeća kao stručnjak dok potiče stručnost kod drugih. Sudionici participirajućih kultura kontinuirano su motivirani za postizanje novog znanja ili poboljšanje postojećih vještina. Iz navedenih razloga, participirajuće kulture / prostori afiniteta / zajednice prakse nude snažne prilike za učenje (Jenkins i sur., 2007).

$\mathrm{Na}$ više se načina razlikuju od formalnih obrazovnih sustava. Formalno je obrazovanje često konzervativno i statično, a informalno - eksperimentalno, razvojno i inovativno. Strukture koje podržavaju formalno obrazovanje su institucionalne, a one koje podržavaju informalno učenje više su provizorne. Informalne zajednice učenja često se razvijaju i mijenjaju kako bi odgovorile na trenutne interese i kratkoročne potrebe, dok institucije javnog obrazovanja ostaju neznatno promijenjene unatoč desetljećima obrazovnih reformi. U informalne zajednice učenja možemo ulaziti ili iz njih izlaziti, ako ne uspiju zadovoljiti naše potrebe, dok u formalnom obrazovanju ne uživamo u takvoj mobilnosti (Jenkins i sur., 2007; Jurić, 2007). Dakle informalno obrazovanje ostvaruje se u "naglašenim socijalizirajućim situacijama" (Jurić, 2007, str. 70) i promjenjivim socijalnim okvirima.

\subsection{PRINCIPI UČENJA}

Wenger (1996) nudi razumijevanje učenja povezano uz izmijenjenu perspektivu o tome kako se ono odvija, što je potrebno kako bi se učenje podržalo, a time i na čemu se temelji organizacija učenja. Temeljne elemente takve perspektive o učenju on eksplicira kroz niz od sedam principa (Wenger, 1996):

1. Učenje je imanentno ljudskoj prirodi. Ono nije odvojena aktivnost, već se gotovo stalno događa, bez obzira doživljavamo li svjesno svoje učenje i njegove rezultate ili ne. Poučavanje ne uzrokuje učenje. Ono što se nauči ne treba biti istovjetno onome što se poučavalo. Dakle nije potrebno niti moguće poučavanjem "stvoriti" učenje. Poučavanjem je potrebno stvoriti okolnosti koje potiču i osnažuju učenje te ga čine produktivnim.

2. Učenje je socijalni proces. Ono omogućuje socijalnu participaciju. Toliko je integrirano u socijalno sudjelovanje da ga od njega ne možemo odvojiti. Učenje je socijalno - čak i kad ne uključuje neposredne interakcije s drugim ljudima, naše misli, riječi, vrijednosti i sl. odražavaju naše društveno sudjelovanje. Iako se učenje zasniva na neurološkim procesima pojedinca, ono te procese smješta u socijalni kontekst u kojem informacije doživljavamo kao smislene. Zbog svega toga, učenje je najučinkovitije kad je integrirano u socijalno sudjelovanje.

3. Učenje nas mijenja. Ono mijenja ono što mi jesmo, mijenja našu sposobnost sudjelovanja u svijetu. Transformiranjem našeg odnosa sa svijetom, učenje transformira naš identitet. Kroz navedene promjene uzrokovane učenjem izgrađujemo nove vještine, konstruiramo nova znanja, ali i razumijevamo sebe u drugačijem kontekstu. Vidimo 
se u novom svjetlu, a razvijene vještine i izgrađene kompetencije pritom postaju dio smislenog načina našeg sudjelovanja u svijetu.

4. Učenje se odvija kroz angažman u praksi. Identitet, tj. naše iskustvo o njemu, nije apstraktno. Ono implicira sposobnost angažiranja na konkretne načine te prepoznavanje sebe kao člana određene zajednice. Radi se o mogućnosti sudjelovanja u praksi, u socijalno definiranim aktivnostima i o našoj mogućnosti pridonošenja zajednici. Takvo aktivno sudjelovanje u praksi određuje ono što učimo i ojačava nas da budemo ono što jesmo. Jer ono što učimo, čemu pridajemo važnost, čemu imamo pristup, sve je to duboko oblikovano našim praktičnim angažmanom u raznim socijalnim aktivnostima.

5. Učenje odražava sudjelovanje u zajednicama prakse. Već smo rekli da je učenje povezano s našim angažmanom u socijalno definiranim praksama. To podrazumijeva da zajednice u kojima se ostvaruju određene prakse igraju važnu ulogu u oblikovanju učenja. Svi mi pripadnici smo mnogih takvih zajednica prakse. Neke su od njih formalne, neke informalne, mogu biti harmonične ili pak konfliktne, u nekima igramo ključne uloge, dok u drugima sudjelujemo tek periferno. Neke su središnje za naš identitet, a druge tek slučajne, usputne. Učenje je pritom i sredstvo i rezultat našeg sudjelovanja u raznim zajednicama prakse. Ono je integrirano u iskustvo sudjelovanja; u zajednicama, naš identitet, ono što znamo i činimo, spaja se u jedinstveno iskustvo sudjelovanja. Slika o sebi uključuje i povezanost sa zajednicama i osjećaj vlastite povijesti. Održavanje prakse tijekom vremena produbljuje naša znanja i osigurava potencijal za stvaranje novih znanja. Zajedničko učenje unutar zajednica prakse utječe na identitete sudionika mijenjajući njihov osjećaj o tome na koje načine se mogu angažirati u pojedinim aktivnostima, načine na koje se mogu angažirati u svijetu. Zbog svega toga, kako bi se unaprijedilo učenje, važno je prepoznati značajne zajednice prakse. Međutim njih nije uvijek jednostavno identificirati, jer često ostaju informalne, ali samim tim ne i manje utjecajne.

6. Učenje znači bavljenje granicama. Angažirane praksom pojedinih zajednica i one koji to nisu, dijeli u praksi stvorena granica koju karakterizira specifična perspektiva sudionika svake pojedine zajednice. Kako se zajednice prakse ne mogu stvoriti formalnim podjelama, propisima i sl., one nisu istovjetne organizacijskim granicama unutar institucija (npr. u školi, na poslu). Međutim relevantne su za učenje na brojne načine. S njima se suočavaju novo pridošli članovi prilikom ulaska u zajednicu prakse, a mogu se iskusiti na različite vrlo konkretne načine; od jednostavne nove nepoznate situacije do, npr., nemogućnosti sudjelovanja u dijalogu između članova zajednice. Granice se odražavaju na naše identitete. Kako istovremeno pripadamo različitim zajednicama prakse, učenje uključuje i proces usklađivanja različitih oblika sudioništva. Pritom može doći do napetosti između naših uloga i angažmana u školskom, poslovnom ili kućnom životu, u slobodnom vremenu i sl. Proživljavanje i suočavanje s ovim napetostima i sâmo je proces učenja. Granice zajednica praksi prelaze se i prilikom međusobne suradnje ili koordiniranja njihovih različitih perspektiva. Riječ je o usklađivanju različitih iskustava u različitim praksama. Pritom se može i posredovati učenje od jedne do druge zajednice. Stoga za organizacije učenja granice mogu biti sredstva učenja, jer se učenje često događa kada se granice dosegnu u interakciji. Interakcija ne treba biti formalna (npr. sastanak interdisciplinarnog tima), već je ona češće upravo informalna (npr. školski odmor, stanka za ručak). Izvan interakcija 
postojećih praksi, granice su mjesta gdje se stvaraju nove prakse te su plodno tlo za inovacije. Procesi koji se odvijaju tijekom suradnje između različitih zajednica praksi, kao što su pregovaranje, koordiniranje, razilaženje, spajanje i sl. također predstavljaju učenje.

7. Učenje je međudjelovanje između lokalnog i globalnog. Institucije uključuju više različitih praksi, pa možemo reći da su one konstelacije međusobno povezanih zajednica praksi. Unutar pojedinih zajednica organiziraju se lokalne aktivnosti, ali i doživljava se i iskušava značenje pripadanja širim organizacijama. Velik dio lokalne energije usmjeren je na globalne odnose i pitanja. Tako se stvara slika šireg konteksta u kojem je praksa smještena. U kontekstu posebnih oblika sudjelovanja te se šire kategorije (npr. pripadnost istoj profesiji, spolu, skupini iste kronološke dobi, istoj instituciji i sl.) u praksi doživljavaju kao živi identiteti.

Iako se ove primjedbe o učenju mogu činiti vrlo jednostavnima, pa čak i same po sebi razumljivima, one se često ne iskorištavaju u obrazovnoj praksi, iako su njihove implikacije na oblikovanje učinkovitog poučavanja vrlo duboke i dalekosežne. Wenger (1996) pojašnjava kako pomak u perspektivi učenja, vidljiv kroz navedene principe, ne predstavlja alternativno usmjerenje učenja, već pruža učenju dodatnu dimenziju. Promijenjena perspektiva nas senzibilizira te mijenja način našeg pristupanja problemima učenja. Ona omogućuje istančanost postupaka, tj. pronalaženje odgovarajućeg rješenja za specifične situacije. Navedene primjedbe sugeriraju promjenu u perspektivi učenja koja može proširiti naš fokus mišljenja i djelovanja na širok raspon situacija o kojima treba voditi računa prilikom poučavanja. Pogrešno je pretpostaviti da učenje jedne organizacije ili institucije predstavlja zbir učenja pojedinaca koji ju čine. Zajednice prakse su snaga s kojom treba računati. U slučaju da se u podržavanju učenja previdi potreba za dijeljenjem prakse ili važnost informalnih zajednica, mogu se nesvjesno presjeći osnovni procesi koji omogućuju nastanak i razvoj učenja.

\subsection{Praksa uČenja i pouČavanja}

Dovodeći u odnos tradicionalno viđenje učenja i poučavanja s viđenjem učenja i poučavanja iz perspektive socijalnog konstruktivizma, postaju očite značajne razlike između ta dva pristupa. Gorodetsky sa svojim suradnicima (2003) pruža analizu glavnih karakteristika obaju navedenih pristupa učenju i poučavanju. Karakteristike koje ističu, prikazane su kroz ekstremne pozicije radi bolje slikovitosti, pa bi navedenih sedam kategorija trebalo sagledavati kao opće tendencije prije nego kao jasnu dihotomiju (Gorodetsky i sur., 2003):

1. Proces učenja iniciraju sami učenici, a potječe od pitanja i interesa socijalnog konteksta u kojem su učenici angažirani. Takva problematika u svezi je s brzo mijenjajućom socijalno-tehnološkom kulturom te utječe na budućnost onih koji uče. Ta je situacija učenja značajno različita od one tradicionalne u kojoj je učenje eksterno determinirano kroz prethodno propisani kurikulum koji razvijaju nastavnici, škole ili nadležno ministarstvo.

2. Dok je u tradicionalnom učenju i poučavanju, koje je značajno determinirano kurikulumom, osnovni nastavni zadatak "prenošenje" znanja (koje se smatra 
objektivnim i neutralnim), u konstruktivističkom viđenju učenja i poučavanja učenici su uključeni u razumijevanje problema šire i uže socijalne zajednice. Do razumijevanja se dolazi suočavanjem sa socijalnim pitanjima, misaonim istraživanjem, koje kao pozadinske aktivnosti obuhvaća postavljanje pitanja, opserviranje i analiziranje prikupljenih informacija. $\mathrm{Na}$ taj način određuje se vrijednost informacija, njihovo značenje za istraživani problem. Na vrijednost podataka utječu i učenički specifični pogledi na svijet te njihove osobne preferencije.

3. Prikupljeni podatci sagledavaju se iz perspektive stvarnog svijeta čiji su učenici dio. Pritom konstruirano znanje služi proširivanju i produbljivanju učenikovog razumijevanja, a usmjereno je prema učenikovim potrebama. Sâm proces učenja i konstruiranja znanja usmjeren je domišljatošću, kreativnošću, vrijednostima i svjetonazorima učenika. Znanje koje se izgrađuje položeno je, dakle, u kontekst, a kritička promišljanja o problemu otkrivaju pozadinske svjetonazore i učeničke individualne pretpostavke koje vode do preferiranih "istina". U tradicionalnom kurikulumu znanje je ono što je legitimizirano od strane znanstvene zajednice te je pronašlo svoj put u formalni kurikulum i udžbenike.

4. Kod učenja položenog u kontekst socijalne sredine proces istraživanja problema osigurava smjer i doseg konstruiranja znanja. U tradicionalnom obrazovanju granice sadržaja koje treba shvatiti postavljene su u formalnom kurikulumu, tj. ne postavljaju ih sami učenici, već oni koji razvijaju kurikulum.

5. Učenici i njihovo kulturno okruženje dio su šireg dinamičnog socijalnog sustava koji se neprestano mijenja. Čak može doći i do značajnih promjena u vrlo kratkom vremenu. Iz toga proizlazi da je učenje proces bez prethodno precizno determiniranog smjera ili ishoda, a konstruirano znanje može biti dvosmisleno i nesigurno. Upravo istraživanje unutar trenutnih socijalnih problema otkriva subjektivnost i visoku razinu nesigurnosti prilikom interpretacije prikupljenih podataka, prilikom pronalaženja smisla. Kod poučavanja utemeljenih nastavnih predmeta, postoji tendencija da se prenosi predodžba sigurnosti, tj. postojanje apsolutnih "istina", o kojima se ne diskutira i ne problematizira ih se, a sadržane su u propisanom kurikulumu.

6. U konstruktivističkom viđenju učenja i poučavanja, proces učenja kroz istraživanje predstavlja otvorenu, na učenika usmjerenu situaciju u kojoj odgovornost za učenje leži na učenicima. Poučavanje unutar okvira raspoloživog kurikuluma potiče uobičajeni obrazac poučavanja - "pokrivanje kurikuluma". Pritom o tempu, sekvencama sadržaja i evaluaciji odlučuje neposredno nastavnik, bez uključivanja učenika u navedenu problematiku odlučivanja.

7. Procjenjivanje "efikasnog" učenja obično se temelji na evaluaciji kroz pitanja zatvorenog tipa, koja se odnose na sadržaj učenja (bolje reći poučavanja) ili na ograničeno rješavanje problema. Nasuprot tome, kod konstruktivističkog učenja usmjerenog na istraživanje problema unutar šireg konteksta, mjera uspješnog učenja je sposobnost uključivanja u nova istraživanja, dakle, za sobom povlači daljnji proces učenja.

Na sličan način, Resta i njegovi suradnici (1999) oslikavaju razlike s obzirom na teorijske pozicije iz kojih se promatra nastavnička uloga. Tradicionalna uloga nastavnika u učionici može se opisati na sljedeći način: on je kvalificirani stručnjak za određeno predmetno područje, čija je odgovornost da (Resta i sur., 1999): 
- "prenese" određene nastavne sadržaje, određena znanja, u učeničke umove kroz različite metode poučavanja, od kojih su najčešće usmeno izlaganje i demonstriranje uz učestalo uvježbavanje;

- evaluira uspjeh "prenošenja" znanja koristeći testove i ispitivanja;

- učenicima osigura pomoć, ako je potrebna.

Promjene u nastavničkoj ulozi utemeljenoj na socijalnom konstruktivističkom poimanju učenja i poučavanja odražavaju se na ideji postojanja zajednica izgrađivanja znanja u kojima se nastavnik odmiče od direktnog poučavanja djelujući kao vodič učenicima koji postižu svoje vlastite ciljeve učenja. Takvi su nastavnici manje "konzumenti" postojećeg kurikuluma, a više su usmjereni na uređivanje kurikuluma koji je osjetljiviji na interese učenika. Navedene se promjene u praksi ne događaju jednostavno. One podrazumijevaju nužan odmak od tradicionalnog razumijevanja nastave, konkretne promjene u nastavnoj praksi, nastavnikovom odnosu prema kurikulumu i promjene u ulogama koje nastavnici i učenici igraju u učionici. Učenici više nisu striktno usmjereni na nastavnika koji im treba "isporučiti" kurikulum. Cijela zajednica učenja (koju čine i učenici i nastavnici) ima značajan prostor u definiranju kurikuluma i odgovarajućih nastavnih aktivnosti koje pridonose unapređenju konstruiranja znanja. Promjene nastavne prakse reflektiraju se i kroz transformiranje socijalnih interakcija između članova zajednice učenja, što se podjednako odnosi na nastavnike i učenike. I nastavnici i učenici više i slobodnije surađuju sa svojim kolegama, ali i međusobno, pritom mijenjajući svoj odnos prema kurikulumom određenim sadržajima, prema učenju - zajedničkom konstruiranju znanja i prema poučavanju - poticanju učenja (Resta i sur., 1999).

Wenger $(1991,1996)$ navodi implikacije promijenjene perspektive učenja, utemeljene na postojanju raznovrsnih zajednica učenja, na organizaciju poučavanja. Prvenstveno, mnogo više pozornosti treba pridavati socijalnom životu te cijeniti njegov informalni, inventivni, razvoji potencijal. Jer socijalni je svijet mjesto unutar kojeg se radi, odakle potiču inovacije, gdje se konstruiraju značenja, gdje se učenje svakodnevno odvija i gdje se formiraju identiteti. Učenicima nije dovoljno pružiti nove informacije, već treba podržati njihovo učenje tako što im se otvara mogućnost za participacijom u radu. Kako su vrijednosti i kompetencije utjelovljene u dinamične, živuće, izmjenjujuće, neformalne i informalne zajednice prakse, treba iskoristiti potencijale koje one nude i poticati mnogostruke interakcije između različitih lokalnih kulturnih praksi rada i učenja (Wenger, 1991, 1998, 2004; Eckert, Wenger, 1994; Snyder, Wenger, Briggs, 2004). Kao najpogodniji oblici organizacije nastavnog učenja i poučavanja navode se suradničko učenje, učenje kroz djelovanje, učenje otkrivanjem, istraživanjem (posebice istraživanjem aktualnih problema unutar određenog socijalnog i povijesno-kulturnog konteksta), učeničko izvođenje eksperimenata, projektni rad i sl. (Wenger, 1991, 1996, 1998, 2004; Eckert, Wenger, 1994; Resta i sur., 1999; Witfelt, 2000; Doherty i sur, 2002; Gorodetsky i sur., 2003; Terhart, 2003; Snyder, Wenger, Briggs, 2004; Saab i sur., 2005; Babić, 2007). Sve su to oblici aktivnog učenja kod kojih je naglašen pozitivan doprinos dinamičnih socijalnih odnosa učenika međusobno, učenika i nastavnika te raznih stručnjaka i praktičara čije je iskustvo relevantno prilikom učenja, tj. konstruiranja znanja kroz aktivnosti rješavanja problema, istraživanja i sl. 


\section{ZAKLJUČAK}

Odgojno-obrazovna praksa učenja i poučavanja zasnovana na teorijskim postavkama socijalnog konstruktivizma uzima u obzir učenikova prijašnja znanja, njegove interese, motive i njegovu specifičnu osobnost, sve smještene unutar šire socijalne i tehnološke kulture. Proces učenja nedjeljiv je od konteksta u kojem se odvija. Kontekst učenja utječe na sâme procese $\mathrm{i}$ ishode učenja. Pritom se konstruirano znanje vidi, ne kao cilj koji treba postići zbog njega samog, već kao instrument koji se primjenjuje prilikom istraživanja i rješavanja problema, dakle kroz aktivnost učenika. Razumijevanje se stvara kroz rad ili djelovanje.

Učenje (i poučavanje) bi trebalo provoditi kao relevantno, instrumentalizirano i kontekstualizirano u svakodnevne živote učenika. Takvo je učenje usmjereno na učenike, njihove probleme i pitanja u koja se osjećaju uključenima. Informalni suradnički dijalog otkriva raznovrsne perspektive o pojedinim temama, različite stavove prema njima. Kroz njega se uspostavljaju zajednice učenja utemeljene na potrebama i vrijednostima učenika. To ne znači dokidanje sustavnog poučavanja u korist situacijskog učenja, već poticanje integrativnog učenja. Integrativno učenje učenici doživljavaju kao osobno iskustvo duboko kontekstualizirano u konkretne situacije te u njima primjenjivo, ali istovremeno sustavno i logički povezano s dugoročnim, kumulativnim ljudskim znanjem. Stoga, pored formalnih i neformalnih, i informalne bi oblike učenja, kao i zajednice prakse koje kroz takvo učenje nastaju, trebalo uzimati u obzir u školskom obrazovanju. Bez obzira što ih je teško kontrolirati jer su nestabilni, dinamični, promjenjivi, takvi oblici i okruženja učenja predstavljaju kreativnu snagu obrazovanja.

\section{LITERATURA}

Babić, N. (2007): Konstruktivizam i pedagogija. Pedagogijska istraživanja. 4 (2), str. 217 229.

Becker, H., Riel, M. (2000): Teacher Professional Engagement and ConstructivistCompatibile Computer Use. Teaching, Learning and Computing: 1998 National Survey, Report no. 7.; http://www.crito.uci.edu/tlc/findings.html

Doherty, R. W., Echevarria, J., Estrada, P., Goldenberg, C., Hilberg, R. S., Saunders, W. M., Tharp, R. G. (2002): Research Evidence: Five Standards for Effective Pedagogy and Student Outcomes. Tehnical Report No. 1, Santa Cruz: University of California, CREDE - Center for Research on Education, Diversity and Exelence; http://www.crede.org/tools/ profdev/institute_pix.html

Eckert, P., Wenger, E. (1994): From school to Work: An Apprenticeship in Institutional Identity. Learning and Identity Series. Palo Alto, CA: Institute for Research on Learning.; http://www.ewenger.com/pub/Institutional_identity_wrd.doc

Gee, J. P. (2004): Situated Language and Learning: A Critique of Traditional Schooling. New York: Routledge.

Gorodetsky, M., Keiny, S., Barak, J., Weiss, T. (2003): Contextual pedagogy: Teachers' journey beyond interdisciplinarity. Teachers and Teaching: theory and practice. Vol. 9., No. 1., pp 21-33. 
Jenkins, H., Clinton, K., Purushotma, R., Robison, A. J., Weigel, M. (2007): Confronting the Chalenges of Participatory Culture: Media Education for the $21^{\text {st }}$ Century. Chicago: The MacArthur Foundation.; http://www.digitallearning.macfound.org/atf/cf/\% 7B7E45C7E0A3E0-4B89-AC9C-3807E1B0ae4e\%7D/JENKINS_WHITE_PAPER.PDF

Jurić, V. (2007): Školsko (formalno), neformalno i informalno obrazovanje. u zborniku radova: Pedagogija - prema cjeloživotnom obrazovanju $i$ društvu znanja. Svezak 1. Zagreb: Hrvatsko pedagogijsko društvo. str. 68-80.

Kretchmar, J. (2008): Seymour Papert \& Constructionism. EBSCO Research Starters - Academic Topic Overviews. EBSCO Publising Inc., 5p; http://web.ebscohost.com/ehost// detail? vid=14\& 2 hid=101\&sid

Lacković-Grgin, K. (2006): Psihologija adolescencije. Jastrebarsko: Naklada Slap.

PISA 2009; http://www.pisa.hr/index.php/2009-u-rh/glavno-istrazivanje-2009

Resta, P., Christal, M., Ferneding, K., Kennedy Puthoff, A. (1999): CSCL as a Catalyst for Changing Teacher Practice. Computer Support for Collaborative Learning 1999. Learning Technology Center - University of Texas, pp 488-495.

Saab, N., Van Joolingen, W., Van Hout-Wolters, B. (2005): Communication in collaborative discovery learning. British Journal of Educational Psychology. No. 75., pp 603-621.; http://www.bpsjourlals.co.uk

Snyder, W., Wenger, E., Briggs, X. (2004): Communities of Practice in Government: Leveraging Knowledge for Performance. The Public Manager. Vol. 32. No. 4, pp 17-21

Suárez-Orozco, M., Sattin, C. (2007): Learning in the Global Era. in: Suárez-Orozco, M. /edit./: Learning in the Global Era - International Perspectives on Globalization and Education. Los Angeles: University of California Press. Ross Institute., pp. 1-43.

Terhart, E. (2003): Constructivism and teaching: a new paradigm in general didactics?. Journal of Curriculum Studies. Vol. 35., No. 1., pp 25-44.

Wenger, E. (1991): Communities of practice: where learning happens. Benchmark Magazine. Fall Issue.; http://www.ewenger.com/pub/pub_benchmark_wrd.doc

Wenger, E. (1996): Communities of practice - The Social Fabric of a Learning Organization. Health Care Forum Journal. Vol. 39, No. 4, pp 20-26.; http://www.ewenger.com/pub/ pubhealthcareforum.htm

Wenger, E. (1998): Communities of practice: Learning as a Social System. Systems Thinker. Vol. 9. No. 5, pp 4-13.; http://ewenger.com/pub/pub_systems_thinker_wrd.doc

Wenger, E. (2004): Knowledge managment as doughnut: Shaping your knowledge strategy through communities of practice. Ivey Business Journal. 1, pp 1-8; http://www. iveybusinessjournal.com

Witfelt, C. (2000): Educational Multimedia And Teacher's Needs For New Competencies: A Study Of Compulsory School Teacher's Need For Competence To Use Educational Multimedia. EMI (Education Media International) - Euro Education. 37:4. pp 235-241. http://www.tandf.co.uk/journals 


\title{
Learning Through the Prism of Social Constructivism
}

\begin{abstract}
SUMMARY
In today's understanding of human development and learning is increasingly emphasized the importance of contextual, particularly social impacts, as well as their dynamic interactions between the individual and vice versa, individual to them. A dynamic co-construction of these relationships creates an individual, where he was an active actor in the dynamics of change occurring in him, but in the surrounding area. Knowledge, skills, competencies are constructed based on the existing human experience and the context in which learning occurs. Fundamental changes in learning and teaching are the transition to an open system of knowledge and the focus on the very processes of learning. Learning and teaching are opened and viewed in a much larger material, social and cultural context than those closely educational. All this requires a redefinition of the curriculum, creating an enabling environment for teaching and learning, but also changed the general approach in teacher education.

A short review of current constructivist interpretation of learning and the context in which it occurs is presented in the paper. The particular emphasis is placed on social constructivism, communities of practice/learning and the informal forms of learning. The paper provides an overview of the revised perspective on learning through a series of seven principles, and, ultimately, the reflection theory of social constructionism to the practice of school learning and teaching, as well.
\end{abstract}

KEY WORDS: communities of practice/learning, constructivism, context, informal learning, learning, learning principles, social constructivism, teaching 